\title{
Standards of quality for outdoor recreation in Tatra National Park: a contribution to integrated visitor monitoring and management
}

\author{
Eva Streberová \& L'ubica Jusková
}

Keywords: Tatra National Park, standards, crowding, outdoor recreation

\section{Abstract}

Profile

The aim of the study presented in the paper was to determine standards of quality for outdoor recreation in Tatra National Park in Slovakia. A survey was carried out in two nature reserves in the park, Mlynická Valley and Studené Valleys, during the 2012 and 2013 summer seasons. The questionnaire focused on several topics relevant for visitor management. In this paper we present partial results of the survey, focusing on visual simulations for crowding and vegetation loss. Findings from both study areas point towards the need for management action since preferred conditions for both indicators had been exceeded.
Protected area

Tatra National Park

Mountain range

Carpathians

Country

\section{Slovakia}

\section{Introduction}

In the late 1960 s the concept of carrying capacity gained popularity among scientists and managers of protected areas, who applied it in the management of particular habitats or ecosystems and in tourism management. Since the early scientific applications of this concept, it has been suggested that the perspective should be more complex, including human values, aims, institutional settings and management practices (Manning et al. 1996). In relation to tourism management in protected areas, carrying capacity is often defined as "a maximum number of visitors that can be tolerated without irreversible or unacceptable deterioration of physical environment and without considerably diminishing user satisfaction" (Seidl \& Tisdell 1999, 401). Social carrying capacity of visitors can be framed in terms of visitor standards for certain environmental or social conditions of recreational areas, based on normative theory adapted from social sciences (Manning \& Freimund 2004; Manning 2013). This concept is related to the emergence of a new field - recreation ecology, which studies the impacts of outdoor recreation on natural or semi-natural environments and their effective management (Monz et al. 2010). Studies on this topic originating from North America represent well comparable and focused research efforts with a long research history. In Europe, the situation is quite the opposite - in terms of research volume, recreation area settings (ranging from highly developed, suburban to remote areas) and different methodological approaches (Arnberger \& Mann 2008; Burns et al. 2010). The majority of studies deals with hikers and campers. A number of publications have dealt with boating or fishing standards on lakes and rivers (Grossman et al. 2004; Manning et al. 2010; Anderson et al. 2012). More recent studies focus on measuring and managing

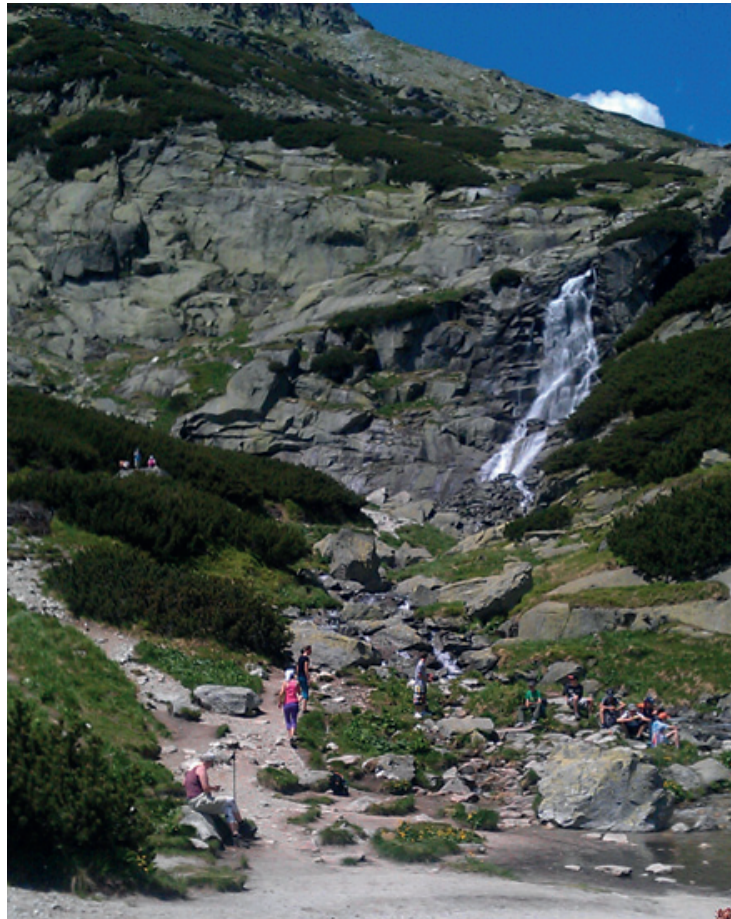

Figure 1 - Skok waterfall, Mlynická Valley.

the quality of transportation in protected areas (Hallo \& Manning 2010; Pettengill et al. 2012) or other leisure activities in protected areas like riding on horseback, cycling, climbing, etc. (Manning \& Valliere 2001; Monz 2009).

In this paper we evaluate social norms of hikers for preferred and acceptable environmental and social conditions in two nature reserves in Tatra $\mathrm{Na}-$ tional Park (TANAP) in Slovakia, which are among the most crowded during summer seasons. Although the research on ecological carrying capacity in TANAP has a long tradition, the research on social carry- 
ing capacity of visitors and management of outdoor recreation is rather limited in Slovakia (Šeffer 2007; Švajda et al. 2013). Information on visitors to TANAP is available mainly in a quantitative form (the number of overnight stays, parking and cable car tickets, etc.). The total number of visitors to TANAP can be only estimated since no complex visitor monitoring system exists (Švajda 2009). Every summer since 1972, an annual one-day visitor monitoring has been carried out place in TANAP (usually in August), when tourists are counted manually on hiking trails from 5 a.m. to 7 p.m. In the 1970 s and 1980 s, the era of mass tourism, construction of accommodation and winter sport facilities in TANAP increased sharply and this trend continued through the 1990s. Visitor numbers peaked in the late 1980s when more than 5 million visitors were estimated to visit the park annually, the majority of them coming in summer. The maximum number of visitors per day in the history of TANAP occurred in July 1981, when during the annual monitoring 26520 visitors were counted on the trails in TANAP, including the entries of visitors coming from the Polish Tatrzańsky Park Narodowy (Šturcel 1990). As a response, the interest in ecological carrying capacity research grew. The proposed limits of hiking trails in TANAP were set at 7500-14200 visitor per day, based on ecological carrying capacity of either soils (Midriak 1989), landscape structure and functions (Drdoš 1989; Hrnčiarová et al. 1997), or surrounding vegetation (Piscová 2007; Šoltés \& Šoltésová 1989). In the last decade, tourism development has slowed down, except for winter sports tourism. Recent data on August visitor monitoring oscillate between 16000-22000 visitors per day during the summer season, which is well above the mentioned limits (Pitoňák 2014) (Figure 2). Yet no regulation mechanisms have been introduced to manage visitors, except for winter closures of trails at the highest elevations and limits for visiting some of TANAP's peaks. A complex interdisciplinary approach is needed to consider the park's carrying capacity from a broader perspective.

During the 2012 and 2013 summer seasons we conducted a survey of 312 respondents in total, aimed at gathering qualitative information on visitors coming to TANAP. In this paper we present some of the study findings, focusing on the preferences of 211 visitors on vegetation loss on trails and on crowding in the Studené and Mlynická Valleys in TANAP. We believe our research has yielded findings which, on the one hand, complement existing results on ecological carrying capacity of the park and, on the other, contradict the current perception of the visitor as a consumer of mass tourism.

\section{Study areas}

The Tatra Mountains (the Tatras) are the highest mountains in Slovakia and also in the Carpathian Belt

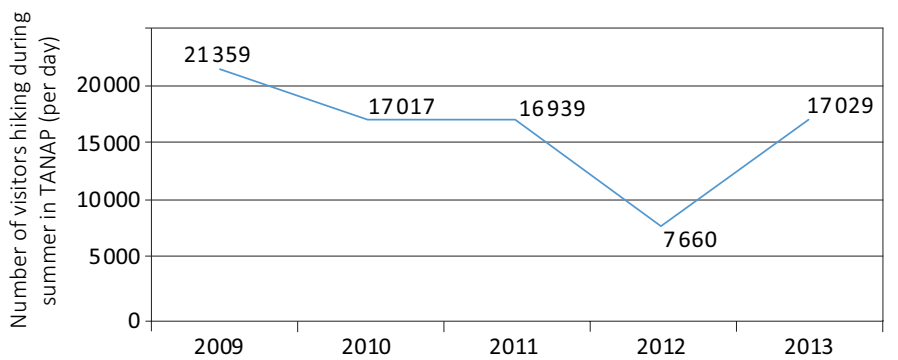

Figure 2 - Results of annual one-day visitor monitoring in TANAP, always in August. In 2012 bad weather on the day of monitoring depressed visitor numbers.

as a whole and constitute a natural border between the Slovak Republic and Poland (Figure 3). They are about $60 \mathrm{~km}$ long from east to west. Recognizing the uniqueness of the Tatras, the two neighbouring countries designated national parks on either side of the border. The Slovak Tatra National Park (TANAP) was created in 1949. In 1954 Tatrzańsky Park Narodowy (TPN) was designated in Poland. The Slovak TANAP stretches over the most valuable parts of the Tatras and is bordered by geographical coordinates of $\mathrm{N} 9^{\circ} 05^{\prime}-49^{\circ} 20^{\prime}$ and $\mathrm{E} 19^{\circ} 35^{\prime}-20^{\circ} 25^{\prime}$. The park itself covers an area of $738 \mathrm{~km}^{2}$ and the surrounding buffer zone another $307 \mathrm{~km}^{2}$. In 1993 the Tatras became a bilateral biosphere reserve of the UNESCO Man and the Biosphere Programme. From a geomorphological point of view the Tatras consist of two units: the Western Tatras and the Eastern Tatras. The Eastern Tatras subdivide into the High Tatras and the Belianske Tatras. The complex geological evolution of the Tatras has allowed a great diversity of flora and fauna to develop. Today the Tatras represent one of the last refuges of the Tatra chamois (Rupicapra rupicapra tatrica) in Europe as well as the brown bear (Ursus arctos) and other large carnivores, e.g. the wolf (Canis lupus), the northern lynx (Lynx lynx), the common wildcat (Felis sylvestris), etc. Before establishment of TANAP in 1949 land use had focused on forestry and cattle breeding. The town of Vysoké Tatry, located at the core of the national park, became the centre of tourism development at the foothills of the High Tatras in the late $19^{\text {th }}$ century. Currently the municipality comprises 15 districts; the most developed and crowded ones are Tatranská Lomnica, Štrbské Pleso, Starý Smokovec (Lukniš 1973; Vološčuk 1994).

The study areas are two nature reserves located in the central part of TANAP: Mlynická Valley and Studené Valley. They are among the most popular and crowded valleys under strict nature protection. There is no hiking trail leading to these nature reserves from the Polish TPN, they can only be accessed from Slovakia. Many visitors choose to hike in Mlynická Valley since it is easily accessible from Štrbské Pleso. With its total area of $7 \mathrm{~km}^{2}$ Mlynická Valley does not belong to the largest reserves in TANAP. However, it displays ecosystems of all altitudinal zones available 


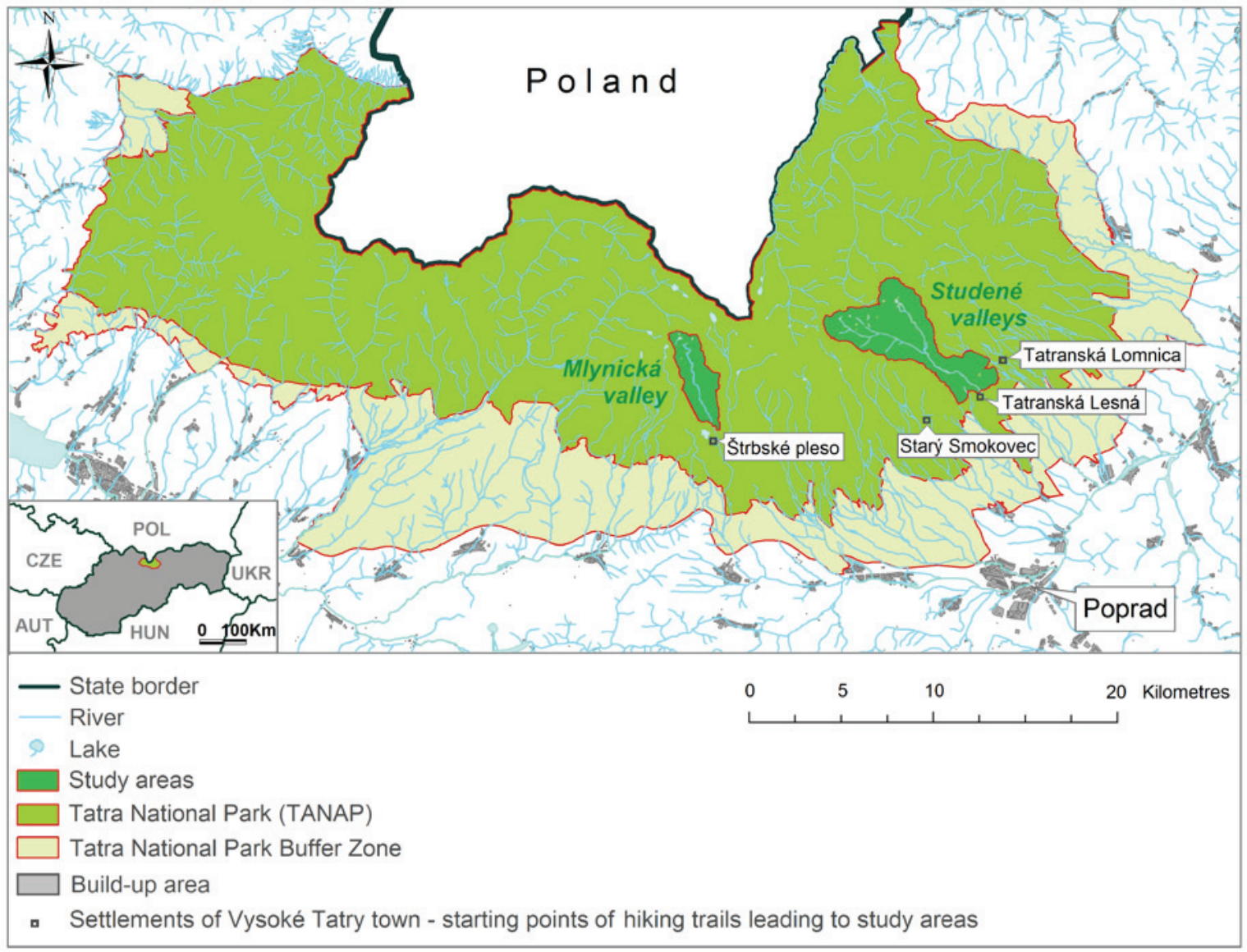

Figure 3 - Study areas in Tatra National Park (TANAP). Source: QGis 2014

in the Tatras. Within a 1.5 hour hike from Strbské Pleso, visitors can reach the scenic waterfall Skok which forms $25 \mathrm{~m}$ cascade (1747 m a.s.l., N 4909'11,45”, E $\left.20^{\circ} 02^{\prime} 45,30^{\prime \prime}\right)$. The trail continues above the waterfall and over the Bystrá Lávka pass (2300 m a.s.l.) into the neighbouring Furkotská valley and back to Štrbské Pleso. Another option of getting to Skok is taking a lift to the Furkotská valley and hiking in the opposite direction through the same pass to the Mlynická Valley. The recommended capacity for the Mlynická Valley is a maximum of 475 visitors per day with regard to its ecological carrying capacity (Midriak 1989; Šoltés \& Šoltésová 1989). According to the results of the August visitor monitoring in the last five years, Mlynická Valley received approximately $700-900$ visitors per day (Pitoňák 2014), which is well above the proposed limits.

The other study area is the Studené valleys nature reserve, which is three times as large as the Mlynická Valley. The reserve is of a Y shape, formed by the Small Studená valley and the Large Studená valley. However, before visitors continue hiking in either valley, they usually visit the Waterfalls of Studený stream (1 $244 \mathrm{~m}$ a.s.l., N 49 9'47.52', E 20¹3' 30.72"). These waterfalls are easily accessible by hiking either from Tatranská Lomnica, from Tatranská Lesná or from Starý Smokovec (here there is a cable car service on this trail). Hiking on each of these trails to the Waterfalls of Studený stream takes roughly
1.5-2 hours. Thus the waterfalls represent a complicated crossroads of various trails leading into three different settlements. The recommended summer visitor capacity for the Waterfalls of Studený stream is 250-650 visitors per day with regard to its ecological carrying capacity (Drdoš 1989; Midriak 1989). According to the results of the August visitor monitoring, approximately 1600-2200 people visited the waterfalls in the last five years (per day, in good weather conditions) (Pitoňák 2014).

\section{Methodology}

The survey was carried out on visitors chosen randomly while hiking in TANAP who were asked to participate in an anonymous on-site face-to-face interview. In early May 2012 we conducted a pilot survey on a sample of 30 respondents to finalize the questionnaire and question format. The main survey took approximately 65 days from late May - September in 2012 and 2013, including weekends and public holidays ( 9 a.m. -5 p.m.). The questionnaire was designed to gather information on several topics relevant to visitor management. In this paper we present the survey results of visual simulations collected in the surroundings of Skok waterfall (in Mlynická Valley, $\mathrm{N}=105$ ) and the Waterfalls of Studený stream (in Studené valleys, $\mathrm{N}=106)$. 


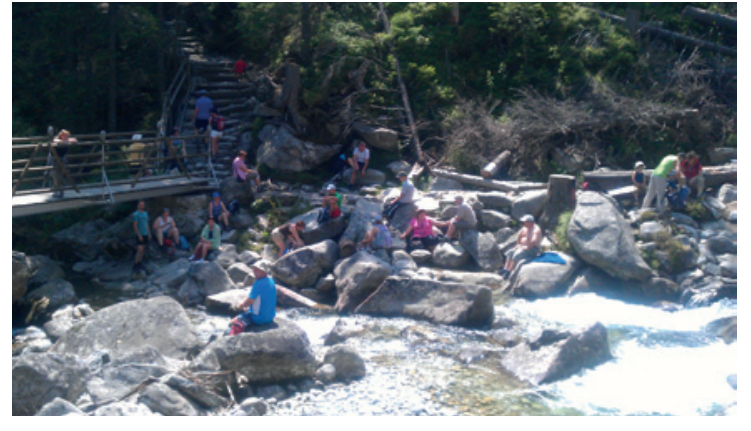

Figure 4 - Crowding at the Waterfalls of Studeny' stream.
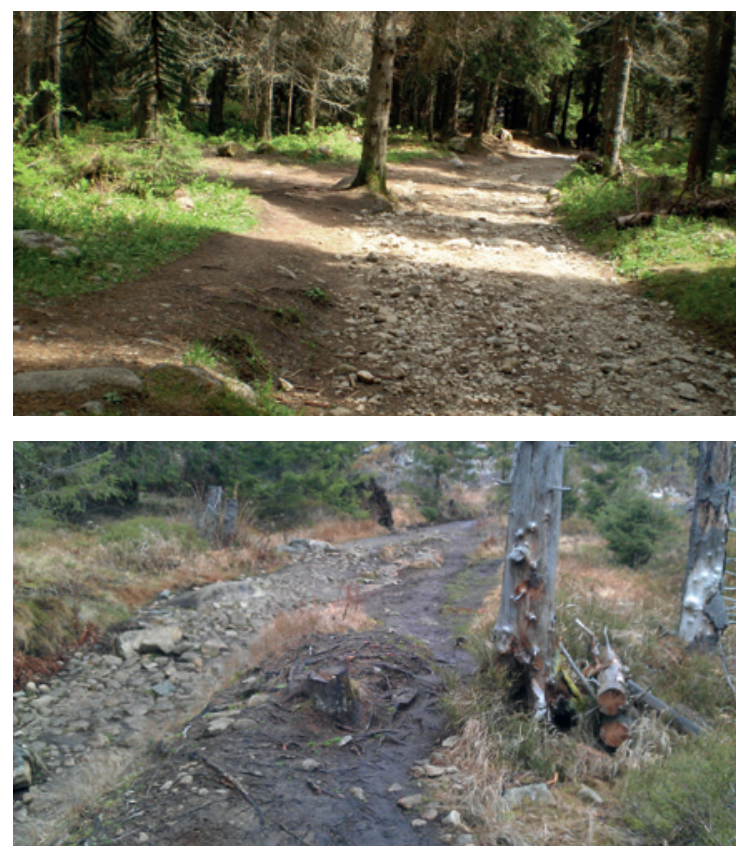

Figure 5 - Vegetation loss due to trampling on a biking trail in Mlynická Valley.

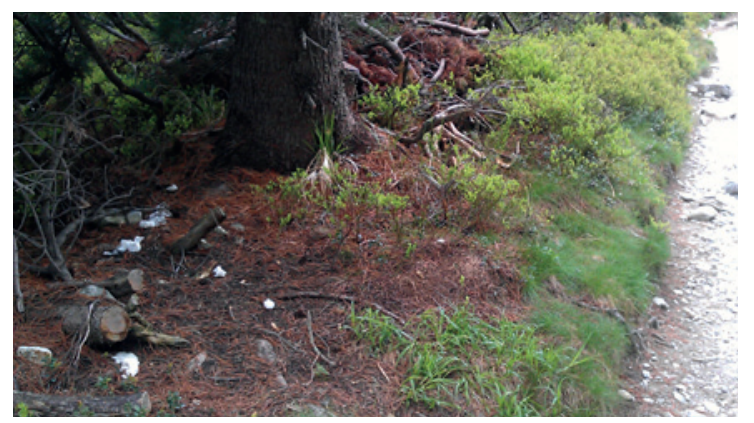

Figure 6 - Littering in Mlynická Valley.

According to Manning (2013) social norms of visitors can be measured by aggregating data received from visitors in a survey and calculated for mean (average) or median values. Acceptability to respondents (visitors) of conditions represented by a set of photographs can be presented in a graph. The photographs are rated using a Likert-type scale, where the conditions under evaluation are displayed on the horizontal axis (i. e. the number of people on the photograph) and the Likert-type scale on the vertical axis. Subsequently the average score of each photograph is then displayed in a graph. The resulting line (connecting the average scores), in the literature referred to as the norm curve, can be interpreted in terms of range of acceptable conditions (positive scores), normative standards (minimum acceptable conditions, where the norm curve cuts the horizontal axis) and unacceptable conditions of visitor impact (negative scores). The level of consensus about a social norm (the dispersion of data around the points defining the curve) is referred to as crystallization (Manning et al. 1996; Manning et al. 2002; Manning \& Freimund 2004; Manning 2013).

In order to establish such norm curves for crowding and vegetation loss we created a set of photographs showing an increasing number of people at Skok waterfall and at the waterfalls of Studený stream. Similarly, another set photographs was created to show vegetation loss as a result of trampling in Mlynická Valley. We used a long question format (e.g. we asked the respondents to rate the acceptability of every photograph in each set) by using a seven point Likert-type scale, where $+3=$ very acceptable condition (optimum) and $-3=$ very unacceptable condition. The results were interpreted as graphs in terms of preferred (optimum) conditions, normative standard (minimum acceptable condition), range of acceptable conditions and unacceptable conditions requiring management action. For norm crystallization we calculated standard deviations of scores per photograph (Manning et al. 1996: Manning 2013). In addition, we asked the respondents how many people they had encountered on their trip, which was then compared with the results of visual simulations. The photographs were edited in Paint.NET 3.5.10 and data were evaluated in Microsoft Excel 7 and PASW Statistics 18.

\section{Results}

\section{General visitor characteristics}

Visitors (respondents) were randomly selected while hiking in either of the two valleys. $56 \%$ were female and $44 \%$ male. Most visitors were aged between $30-49$ years $(38 \%)$, the second largest group (35\%) were those of $50+$ years. The rest were visitors under 29 years $(27 \%)$. As for their nationality, unsurprisingly $74 \%$ were Slovak, then 18\% Czech, 2\% Polish and $2 \%$ each German and Dutch. Other nationalities, statistically insignificant, included Estonian and Hungarian. To characterize visitor behaviour we asked the respondents about their length of stay, average daily spending, preferred types of accommodation, transport, etc. On average the visitors stayed for 6.5 days. The most frequent visitors' activities were hiking, walking, photographing and enjoying the landscape and scenery, photographing wildlife or going on guided hikes. The least preferred activities were rowing, cycling, camping, sightseeing and other sports activities. We asked the respondents about their motivation for coming to the Tatras. The most frequent answers 


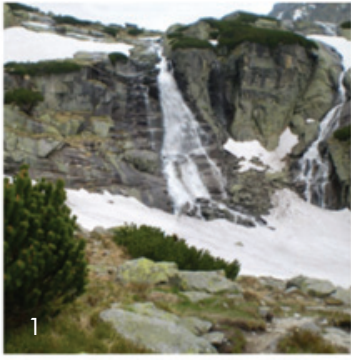

0 people

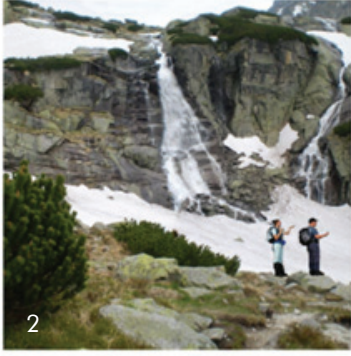

2 people

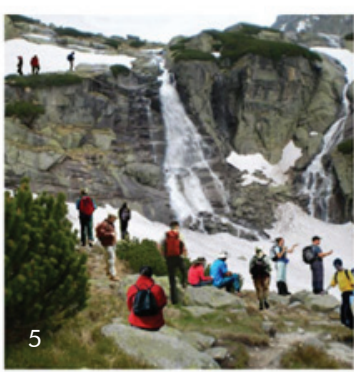

14 people

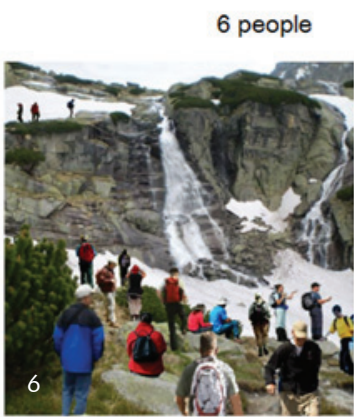

18 people
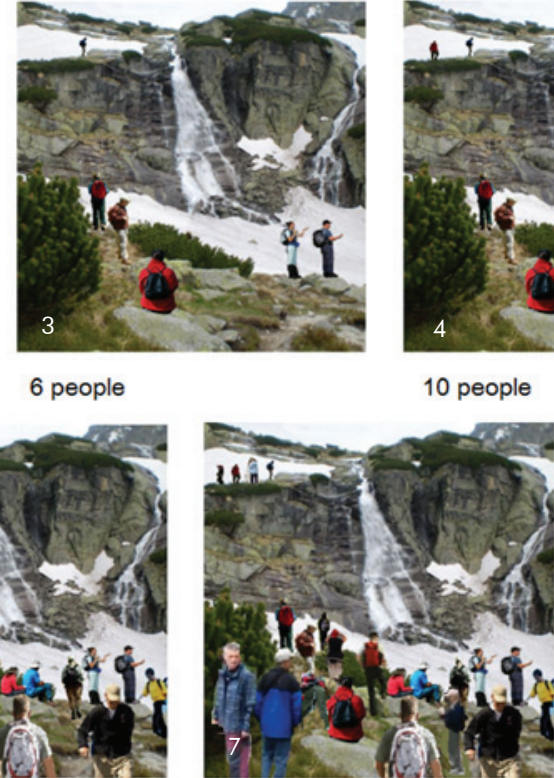

22 people



0 people

Figure 7 - Set of photographs used for visual simulation of crowding at Skok waterfall in Mlynická Valley.

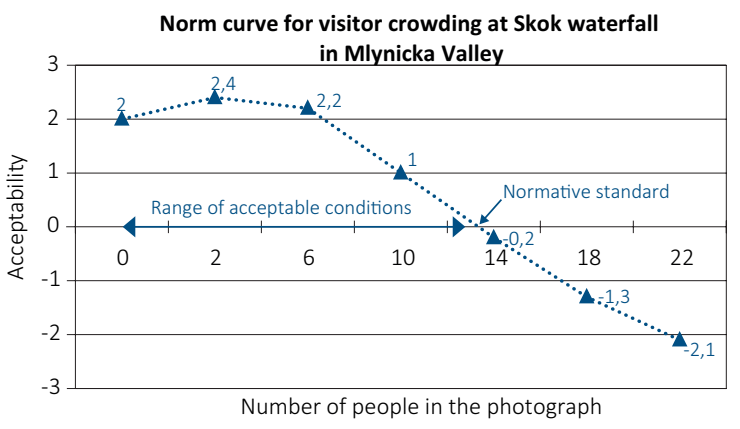

Figure 8 - Interpretation of standards for crowding at Skok waterfall.

Table 1 - Results of visual simulation of crowding at Skok waterfall.

\begin{tabular}{|l|r|r|r|}
\hline $\begin{array}{l}\text { Photo- } \\
\text { graph }\end{array}$ & $\begin{array}{r}\text { Number of people } \\
\text { in the photograph }\end{array}$ & $\begin{array}{l}\text { Average pho- } \\
\text { tograph score }\end{array}$ & $\begin{array}{l}\text { Standard devi- } \\
\text { ation (sample) }\end{array}$ \\
\hline 1 & 0 & 2 & 1.88 \\
\hline 2 & 2 & 2.4 & 1.29 \\
\hline 3 & 6 & 2.2 & 1.24 \\
\hline 4 & 10 & 1 & 1.65 \\
\hline 5 & 14 & -0.2 & 1.88 \\
\hline 6 & 18 & -1.3 & 1.77 \\
\hline 7 & 22 & -2.1 & 1.69 \\
\hline
\end{tabular}

were: nature, active rest, hiking, the Tatras, high mountains and spending time with family and / or friends.

Setting standards for crowding and trail conditions in Mlynická Valley

Along the trail leading to the attractive Skok waterfall the impacts of high visitor numbers are clearly visible - especially vegetation trampling, illegal trails and littering (Figures 5, 6). We created two sets of photographs - one showing crowding in the vicinity of
Skok (Figure 7) and the other showing vegetation loss on the trail in Mlynická Valley as a result of trampling (Figure 9). The results of visual simulations were interpreted in a graph (Figure 8) (Manning 2013) and the level of consent to each score is expressed as standard deviation (Table 1).

The most preferred condition (optimum) was photograph 2 (showing 2 people). The range of acceptable conditions was photographs $1-4$. Photograph 5 is crucial because acceptability to respondents here is closest to zero. This is where the norm curve cuts the horizontal axis, which would be approximately 13 people at Skok - i.e. their normative standard (Figure 8). The last two photographs received the lowest scores and represent unacceptable conditions. The lower the value of the standard deviation, the greater the respondents' consent to the photograph's score. As can be seen in Table 1, the lowest standard deviation values are those of photographs 2 and 3, i. e. the most preferred condition. Typically the visitors estimated they had encountered 34 people on average at Skok waterfall, which is more than their normative standard.

Besides crowding, another common problem in Mlynická Valley is the trampling of vegetation surrounding the trail which causes vegetation loss and trail erosion. In general the trail is $1.5-2.5 \mathrm{~m}$ wide. We took a photograph of a $15 \mathrm{~m}$ long section of the trail approximately $400 \mathrm{~m}$ from where the trail enters the forest near in Štrbské Pleso. Here the trail width reaches $6.5 \mathrm{~m}$ (photograph 6 in Figure 9). We used this section of the trail for creating visual simulations. In photograph 3 (Figure 9) we modified the amount of vegetation to create a trail of the usual width - i.e. with $0 \%$ vegetation loss $(1.5-2 \mathrm{~m})$. Photographs 1 and 2 were modified to represent minimal trampling impact: $-20 \%$ vegetation loss in photograph 1 and 


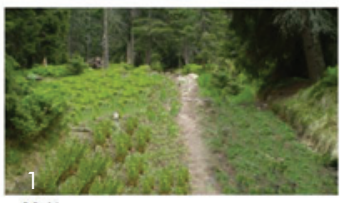

$-20 \%$

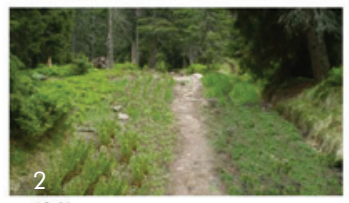

$-10 \%$

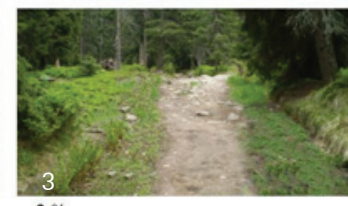

$0 \%$

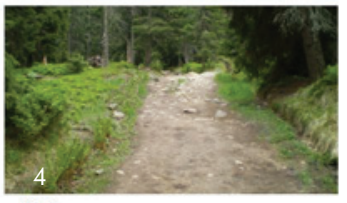

$10 \%$

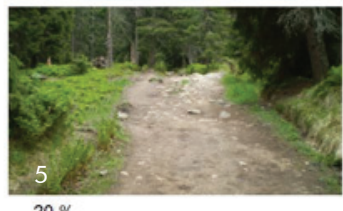

$20 \%$
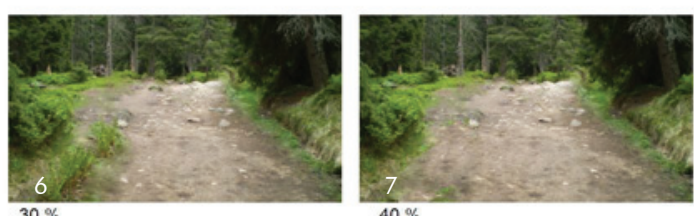

Figure 9 - Set of photographs for visual simulation of vegetation loss on the biking trail in Mynická Valley.

$-10 \%$ vegetation loss in photograph 2 . In photographs $4-7$ the trampling impact is increasing from $+10 \%$ up to $+40 \%$ vegetation loss.

Table 2 shows the average score for conditions shown in each photograph with accompanying standard deviations. The results of visual simulation are also interpreted in a graph in Figure 10 (Manning 2013). This graph shows that the most preferred condition is photograph 3 , with the vegetation loss modified to match the general trail width. The range of acceptable conditions is represented by photographs $1-4$. The score for photograph 5 is the closest to zero. Here the norm curve crosses the horizontal axis at $18 \%$ increase in vegetation loss. This means that the normative standard is approximately $18 \%$ of the increased vegetation loss. If we look at the standard deviations values in Table 2, we can see that respondents' consent was the strongest to photograph 3 (preferred conditions).

Setting standards for crowding at the waterfalls of Studený stream in Studené Valleys

Similarly to Mlynická Valley, we created a set of photographs showing an increasing number of people at the very popular waterfalls of Studený stream (Figure 11). Most of the hiking trails in this area have wooden barriers or are in a steep terrain with rocky substratum, therefore trampling and illegal trails are barely present. In addition to high visitor numbers, other visitor impacts were observed during field research, such as like littering, vandalism or other behaviour not in compliance with visitor regulations (especially feeding wildlife, bathing in the stream, etc.) (Figures $13 \& 14$ ).

The results of visual simulations with accompanying standard deviations are shown in Table 3 (Manning 2013). The resulting norm curve in Figure 12 illustrates the decreasing level of respondents' acceptance of an increasing number of visitors in the set of photographs. The most preferred condition (optimum) is photograph 2 (8 people), with the minimum standard deviation value. Photograph 5 already shows an unac-

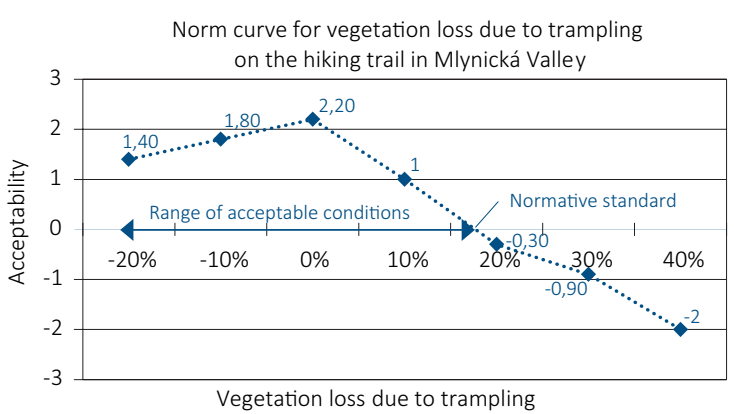

Figure 10 - Interpretation of standards for vegetation gain / loss on the hiking trail in Mlynická Valley.

Table 2 - Results of visual simulation of vegetation loss / gain on biking trial in Mlynická Valley.

\begin{tabular}{|l|r|r|r|}
\hline $\begin{array}{l}\text { Photo- } \\
\text { graph }\end{array}$ & $\begin{array}{l}\text { Percentage of vegetation } \\
\text { gain/loss due to trampling }\end{array}$ & $\begin{array}{l}\text { Average pho- } \\
\text { tograph score }\end{array}$ & $\begin{array}{l}\text { Standard devi- } \\
\text { ation (sample) }\end{array}$ \\
\hline 1 & $-20 \%$ & 1.4 & 2.11 \\
\hline 2 & $-10 \%$ & 1.8 & 1.68 \\
\hline 3 & $0 \%$ & 2.2 & 1.25 \\
\hline 4 & $10 \%$ & 1 & 1.65 \\
\hline 5 & $20 \%$ & -0.3 & 1.77 \\
\hline 6 & $30 \%$ & -0.9 & 1.81 \\
\hline 7 & $40 \%$ & -2 & 1.97 \\
\hline
\end{tabular}

ceptable condition. The remaining three photographs received the lowest scores and represent unacceptable conditions. The range of acceptable conditions is represented by photographs $1-4$. The normative standard (where the norm curve cuts the horizontal axis) is exactly 28 people at the waterfalls at any one time. Like in Mlynická Valley, the respondents in the Studené Valleys were asked to state how many people they had encountered at the waterfalls of Studený stream. Typically visitors had met 31 people on average, which is more than the normative standard. 


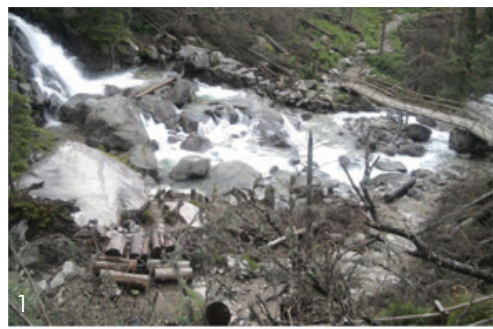

0 people

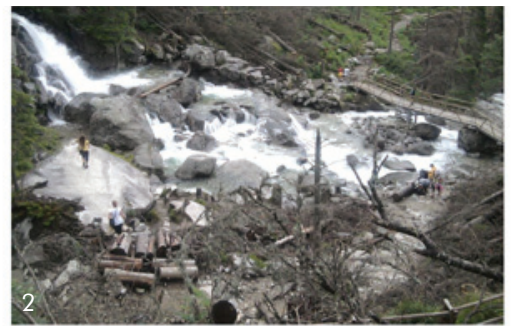

8 people

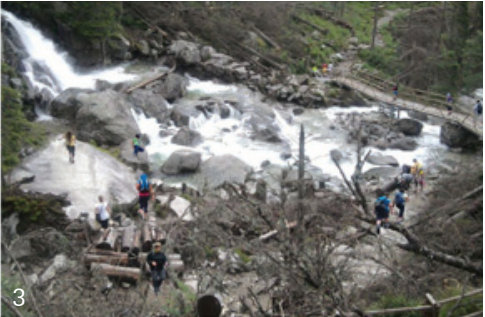

16 people
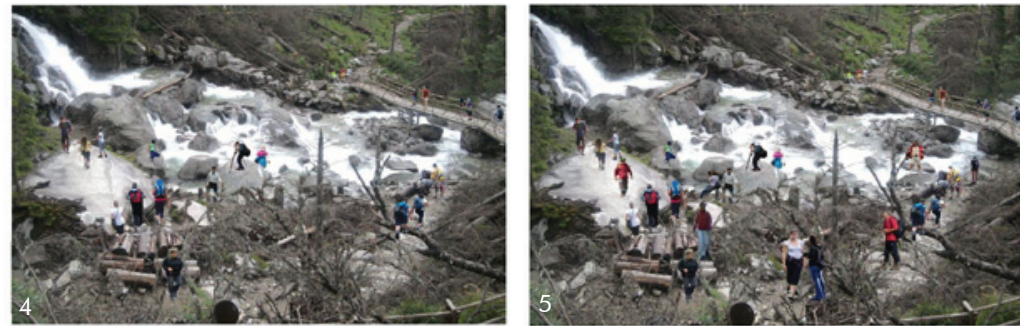

24 people

32 people

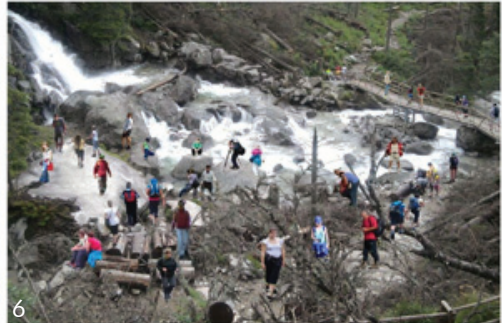

40 people

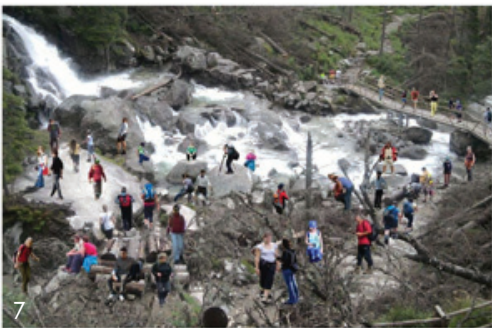

48 people

Figure 11 - Set of photographs used to determine standards for crowding at the waterfalls of Studený stream.

Norm curve for visitor crowding at the waterfalls of Studeny stream in Studené Valleys

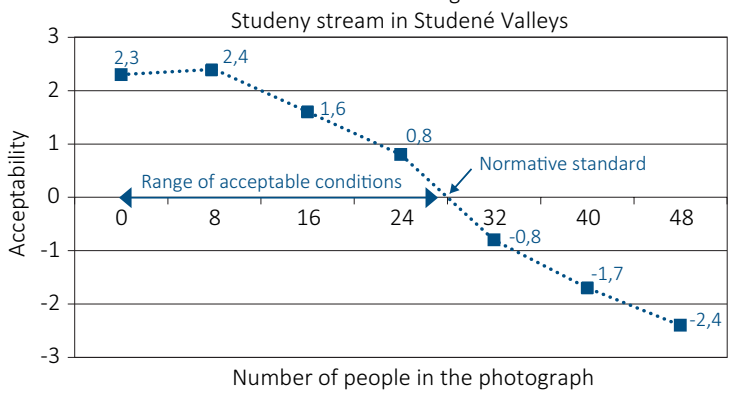

Figure 12 - Interpretation of standards for crowding at the Waterfalls of Studený stream.

Table 3 - Results of visual simulation for crowding at the waterfalls of Studený stream in the Studené Valleys.

\begin{tabular}{|l|r|r|r|}
\hline $\begin{array}{l}\text { Photo- } \\
\text { graph }\end{array}$ & $\begin{array}{l}\text { Number of people } \\
\text { in the photograph }\end{array}$ & $\begin{array}{l}\text { Average pho- } \\
\text { tograph score }\end{array}$ & $\begin{array}{l}\text { Standard devi- } \\
\text { ation (sample) }\end{array}$ \\
\hline 1 & 0 & 2.3 & 1.15 \\
\hline 2 & 8 & 2.4 & 0.72 \\
\hline 3 & 16 & 1.6 & 1.19 \\
\hline 4 & 24 & 0.8 & 1.45 \\
\hline 5 & 32 & -0.8 & 1.83 \\
\hline 6 & 40 & -1.7 & 1.69 \\
\hline 7 & 48 & -2.4 & 1.55 \\
\hline
\end{tabular}

\section{Discussion}

According to the hypothetical model of a social norm curve as proposed by Manning $(2002,2013)$ zero people at any one time at an attractive high-use site in a protected area would be an average visitor's optimum (preferred) condition. This is also supported by many wilderness studies done in North-American national parks, where complete solitude during hiking and minimal visitor impact were most preferred by visitors (e. g. Manning 2000; Anderson et al. 2012; Pettengill et al. 2012). On the contrary, the conditions most preferred by respondents in our study were a minimum presence of other people (photographs with 2 people at Skok waterfall, 8 people at the waterfalls of Studený stream). The respondents often commented that they would fear being completely alone during their hike in the wilderness or they would think they had probably got lost if there was no one else around.

The results of visual simulations for vegetation loss along the trail in Mlynická Valley point towards similar findings. The photographs showing the least visitor impact were not favoured by the respondents and received lower scores than the one showing a 1.5-2 $\mathrm{m}$ wide trail. The visitors' comments on these photographs were they would think they were either on the wrong trail, that it would be too difficult to overtake other hikers on such a narrow trail or that they could not enjoy walking right next to their com- 

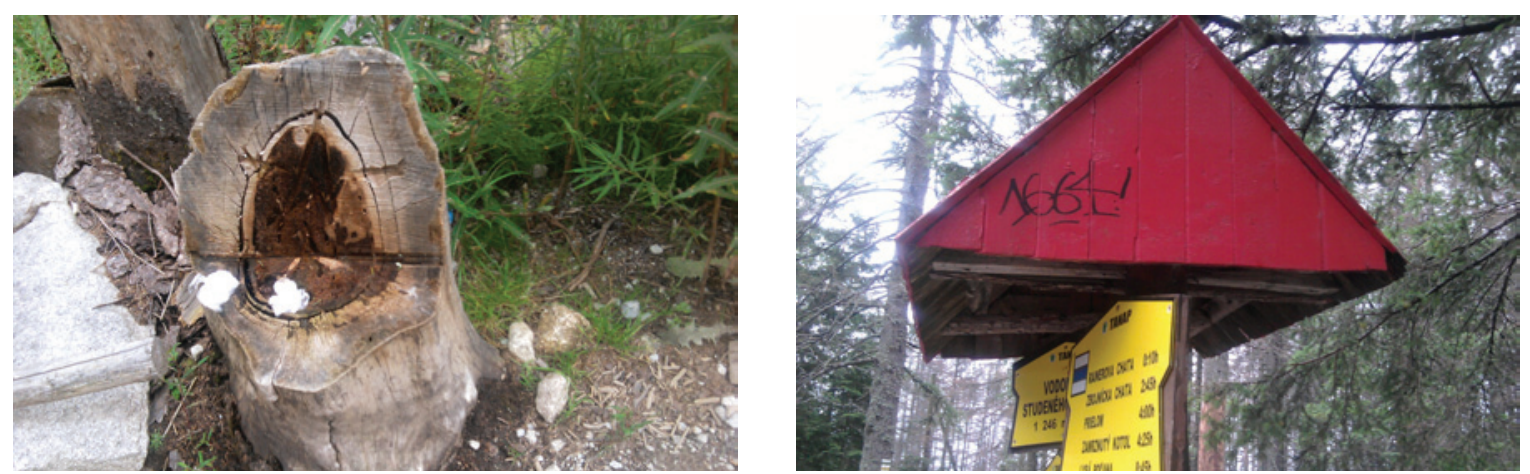

Figure 13 \& Figure 14 - Littering (left) and vandalism (right) in the vicinity of the waterfalls in Studené Valleys.

panion. However, it is important to emphasize, that the North-American norm curve model is based on research done in large remote wilderness areas. The conditions for outdoor recreation in the TANAP nature reserves are those of a national park with a history of intensive tourism development in a setting of highly developed surrounding regions. Supporting evidence can be found in many European studies. For example the comparative study by Burns et al. (2010) came to the conclusion that an area's setting is one of the key factors that influence visitors' perception. Studies dealing with crowding and visitor management in Germany (Grossman 2004; Kalisch 2012) Austria (Burns et al. 2010; Arnberger et al. 2012) and Switzerland (Schamel \& Job 2013) outline that the overall population density in Central Europe is a key factor contributing to high visitor use of protected areas and affecting visitors' sensitivity to crowding.

Across the literature on normative standards for outdoor recreation, we can find several other factors influencing visitors' sensitivity to crowding, e.g.: visitors' previous hiking experience and knowledge of the area, expected crowding, visitor activities and conflicts, visitor characteristics (independent variables), motivation for visiting the area, cultural background, etc. (Vaske \& Donnely 2002). However, as a whole, recent research both in Europe and North America has generated seemingly conflicting results, as every researched area represents a unique case in terms of specific social, managerial and environmental conditions as well as visitors' characteristics (Arnberger \& Mann 2008; Kuentzel et al. 2008). In addition, we believe the choice of research method plays an important role as well. The advantage of using a visual method for setting normative standards is that it offers an explicit and controlled demonstration of environmental and social conditions under evaluation. Furthermore, visualizations communicate the conditions under research to the respondent in an understandable manner, which otherwise seem to be awkward or difficult to describe in narrative or numerical terms (Manning \& Freimund 2004). Since social norm curves are not based on a mathematical model, we considered the number of photographs in visual simulations sufficient. In the case of our two study areas, we have not found any significant correlations between crowding sensitivity and independent variables of visitor characteristics or visitors' previous experience of visiting TANAP. Since the prevailing activities of respondents were not in conflict with visitor motivations and visitor use options in our study areas, it is very unlikely that this might have had an effect on the visitors' norm sensitivity. If we had used a narrative / numerical approach in the questionnaire, it would have been more likely that respondents' answers could be biased by some of the factors mentioned previously.

In addition to visual simulations, we asked the respondents how many people they had encountered at the waterfalls in each study area. On average they reported they had encountered 21 people at Skok waterfall and 31 people at the waterfalls of the Studený stream. When we compare these findings with the graphs in Figures 16 and 24, we can see that both exceed visitors' normative standards for crowding and vegetation loss. One way of dealing with this problem is to cut the transport capacities in the study area (Manning 2000) and build temporary boardwalks (Vistad 2003). Since both valleys are also accessible by means of a lift or cable car, one option would be to limit this service. Another option would be the introduction of entrance fees which, based on the findings of a recent economic study, could improve visitor and resource management of TANAP (Füzyová et al. 2009).

Results of our study have significant implications for the future research on visitor management. Interestingly, the visitors' level of consent was highest for the photographs which received the highest scores in all three sets of photographs. In other words, the norm is the strongest for most preferred conditions. To achieve more conclusive results, further development of our approach is necessary, especially in terms of understanding the implications of norm curves (e.g. norm strength) and applying it in visitor management (Kuentzel et al. 2008). Additional research to guide management decisions in the park should be aimed at visitor strategies for coping with use-related impacts - e.g. crowding, trail erosion, vegetation loss, forest cover loss due to construction and development in the national park (Manning \& Valliere 2001; Schamel \& Job 2013; Švajda et al. 2013) and factors 
that might influence visitors' sensitivity to crowding and other impacts related to visitor use (Tomčíková \& Lehotský 2009).

\section{Conclusion}

The aim of our study was to contribute to existing research based on ecological carrying capacity with qualitative knowledge on visitors' carrying capacity and preferred conditions for hiking during summer, which should be further incorporated in visitor management at TANAP. Social carrying capacity research for outdoor recreation is extremely scarce in the Slovak Republic and so is the practical experience of integrating this kind of knowledge into park management. In order to determine social carrying capacity of visitors, we have adapted the normative approach based on visual simulations (Manning et al. 1996; Manning 2013) and applied it in two national nature reserves in the park, where recommended carrying capacity is exceeded during summer seasons. The normative standard for crowding at Skok waterfall was 13 people and 28 people at the waterfalls of Studený stream. However, visitors typically encountered more people at either site than the number of their normative standard for crowding. Vegetation loss along trails is a frequent visitor use impact in one of the two study areas in TANAP. The current trail conditions were perceived as unacceptable and in conflict with visitors' normative standards. Applying the visual approach in measuring social norms has proved to be an easy to use tool which is familiar to respondents, nevertheless one must bear in mind that standards determined in our study should serve as complementary knowledge to limits already determined by ecological carrying capacity research in TANAP. Definite standards for recreational use should be set in the future with regard to both social and ecological carrying capacities and the aims of park management.

\section{Acknowledgements}

This research was supported by the VEGA project no. 2/0016/11 Socio-ecological factors of strategic planning and landscape management under conditions of democracy and market economy.

\section{References}

Anderson, L.E., R.E. Manning, C.A. Monz \& K.A Goonan 2012. Indicators and Standards of Quality for Paddling on Lake Champlain. Journal of the Great Lakes 38: 150-156.

Burns, R.C., A. Arnberger \& E. von Ruschkowski 2010. Social Carrying Capacity Challenges in Parks, Forests, and Protected Areas: An Examination of Transatlantic Methodologies and Practices. International Journal of Sociology 40 (3): 30-50.
Drdoš, J. 1989. Únosná návštevnost' krajiny v TANAPe. Zborník prác o TANAP 29: 191-237. In Slovak.

Füzyová, L., Lániková, D. \& M. Novorolský 2009. Economic Valuation of Tatras National Park and Regional Environmental Policy. Polish Journal of Environmental Studies 18 (5): 811- 818.

Grossman, J.H., A. Klaphake \& J. Meyerhoff 2004. Canoes versus birds or canoeists versus canoists? Combining interview survey and visitor monitoring to inform visitor management in the Muerits National Park. Policies, Methods and Tools for Visitor Management. In: Sievanen, T., J. Erkkonnen, J. Jokimäki, H. Saarinen, S. Tuulentie \& E. Virtanen (eds.), Finish Forest Institute, Rovaniemi: 274-284.

Hallo, J. \& R.E. Manning 2010. The Denali Park Road experience: Indicators and standards of quality. Park Science 27 (2): 33-41.

Hrnčiarová, T. et al. 1997. Ekologická únosnost'krajiny: metodika a aplikácia na 3 benefićné úremia. Cast' I. - IV. Ekologický projekt, MŽP SR, Svetová banka GEF, ÚKE $S A V$. Bratislava. In Slovak.

Kuentzel, W.F., D. Laven, R.E. Manning \& W.A. Valliere 2008. When Do Normative Standards Matter Most? Understanding the Role of Norm Strength at Multiple National Park Settings. Leisure Sciences 30 (2): 127-142.

Kalisch, D. 2012. Relevance of crowding effects in a coastal National Park in Germany: results from a case study on Hamburger Hallig. Journal of Coastal Conservation 16: 531-541.

Lukniš, M. 1973. Reliéf Vysokých Tatier a ich predpolia. Bratislava, Vydavatel'stvo Slovenskej akadémie vied. In Slovak.

Manning, R.E., D.E. Lime, W.A. Freimund \& D.G. Pitt 1996. Crowding Norms at Frontcountry Sites: A Visual Approach to Setting Standards of Quality. Leisure Sciences 18: 39-59.

Manning, R.E. 2000. Defining and establishing indicators and standards of quality. In: Fulton, D.C., K.C. Nelson, D.H. Anderson \& D.W. Lime (eds.), Human Dimensions of Natural Resource Management: Emerging Issues and Practical Applications. Workshop, 1-3 February 2000. St. Paul.

Manning, R.E. 2007. Parks and Carrying Capacity: Commons Without Tragedy. Washington, DC.

Manning, R.E. 2013. Social Norms and Reference Points: Integrating Sociology and Ecology. Environmental Conservation 40 (4): 310-317. Cambridge.

Manning, R.E \& W.A. Valliere 2001. Coping in Outdoor Recreation: Causes and Consequences of Crowding and Conflict among Community Residents. Journal of Leisure Research 33 (4): 410-426. Urbana.

Manning, R.E., S. Lawson, P. Newman, D. Laven \& W. Valliere 2002. Methodological Issues in Measuring Crowding-related Norms in Outdoor Recreation. Leisure Sciences 24: 339-348.

Manning, R.E. \& W.A. Freimund 2004. Use of Visual research Methods to Measure Standards of Quality 
for Parks and Outdoor Recreation. Journal of Leisure Research 36 (4): 537-579. Urbana.

Manning, R.E., W. Valliere \& J. Hallo 2010. Recreational carrying capacity at Lake Umbagog National Wildlife Refuge. Journal of Fish and Wildlife Management 1 (2): 175-182.

Midriak, R. 1989. Limity zat'aženosti turistických chodníkov $\mathrm{v}$ Tatranskom národnom parku so zretel'om na deštrukciu ich povrchu. Zborník prác o TANAP 29: 239-251. Tatranská Lomnica. In Slovak.

Monz, C.A. 2009. Climbers'Attitudes toward Recreation Resource Impacts in the Adirondack Parks Giant Mountain Wilderness. International Journal of Wilderness 15 (1): 26-33.

Monz, C.A., D.A. Cole, Y. Leung \& J.L. Marion 2010. Sustaining Visitor Use in Protected Areas: Future Opportunities in Recreation Ecology Research Based on the USA Experience. Environmental Management 45 (3): 561-563

Piscová, V. 2007. Zmeny vegetácie Tatier na vybraných lokalitách orplyonených človekom. Bratislava, Veda. In Slovak.

Pitoňák, P. (Specialist staff of State Forests of TANAP) 2014. Provision of information on annual visitor monitoring.

Pettengill, P.R., R.E. Manning, L.E. Anderson, W. Valliere \& N. Reigner 2012. Measuring and Managing the Quality of Transportation at Acadia National Park. Journal of Park and Recreation Administration 30 (1): 68-84. Urbana.

Seidl, I. \& C. Tisdell 1999. Carrying capacity reconsidered: From Malthus population theory to cultural carrying capacity. Ecological Economics 31 (3): 395-408.

Schamel, J. \& H. Job 2013. Crowding in Germany's national parks: the case of the low mountain range Saxon Switzerland National Park. eco.mont 5 (1): 27-34.

Šoltés, R. \& A. Šoltésová 1989. Únosná kapacita okolia turistických chodníkov v TANAPe z hladiska vegetačného krytu. Zborník prác o TANAP 29: 253 334. Tatranská Lomnica. In Slovak.

Šturcel, M. 1990. Návštevnost' vysokohorského prostredia TANAPu. Zborník prác o TANAP 30: 163 178. Tatranská Lomnica. In Slovak.

Švajda, J. 2009. Contribution for improvement of visitor monitoring in the Tatra National Park. eco.mont 1 (2): 13-18.
Švajda J., M. Getzner \& R. Považan 2013. Visitors' perceptions and economic effects of the Tatra National Parks in Poland and Slovakia. In: Šauer P., A. Dvořák \& A. Lisa (eds.), Visegrad countries - Environmental Problems and Policies: 118-126. Prague.

Tomčíková, I. \& M. Lehotský 2009. Perception of riverine landscape (example of the Smrečianska river). Geografický casopis 61 (4): 269-289. In Slovak.

Vaske, J.J. \& M.P. Donnelly 2002. Generalizing the counter-norm-crowding relationships. Leisure Sciences 24 (3/4): 255-269.

Vistad, O.I. 2003. Experience and management of recreational impact on the ground - A study among visitors and managers. Journal of Nature Conservation 11: 363-369.

Vološčuk, I. (ed.) 1994. Tatranský národný park. Martin, Gradus. In Slovak.

Web references

Šeffer, J. 2007. Vyhodnotenie výsledkov prieskumu názorov návštevníkov NP Slovenský raj. Daphne Inštitút aplikovanej ekológie. In Slovak. Available at: http://www.sopsr.sk/projekt2010y/lifeproject/sk/ index.htm (accessed: 05/04/10]

\section{Authors}

Eva Streberová

Completed her $\mathrm{PhD}$ in 2014, on visitor management in Tatra National Park, at the Faculty of Natural Sciences, Comenius University Bratislava. Currently working as researcher at the Institute of Forest Ecology, Slovak Academy of Sciences.

\section{L'ubica Jusková}

A sociologist, currently working as researcher of consumer insights in a private company. As co-author, her main input was the design of the visitor survey presented in this article.

(C) all photographs by the authors 